\title{
Moral education in the Czech territory in the past and the present
}

\author{
Slavomír Lesňák \& Radim Štěrba
}

\begin{abstract}
The following study presents an analysis of the world of moral education in the Czech environment from its recorded beginnings to the current situation in the Czech Republic. The study contains two parts: In the first section, the authors give an account of the history of moral education and different views on it, while in the second section they analyse the current state of moral education. The authors examine the quality of moral education at primary and secondary schools according to the goals of curriculum documents issued by the Ministry of Education, Youth and Sport of the Czech Republic for schools' ethical education programmes and subjects dealing with character development. Based on their own research, they compare set goals with practice, draw conclusions and give recommendations not only to primary and secondary schools, but also to higher education institutions, particularly in terms of introducing professional ethics tools and intensifying their use. The authors suggest expanding the ethical climate at schools to contain the atmosphere of recognition, biophile culture and technological scepticism.
\end{abstract}

Keywords: ethical education, prosocial behaviour, ethical climate, technological scepticism, biophile culture

\section{History of moral education in the Czech Republic}

In the past, moral education in the Czech territory was associated primarily with the Czech cause, particularly in the writings of the first president of the Czechoslovak Republic, professor of philosophy Tomáš Garrigue Masaryk. As the term itself suggests, moral meant belonging to oneself, independent, but also authentic. For centuries, the Czech territories were part of the Habsburg Monarchy, in which the Kingdom of Bohemia had vanished, and where the specific Czech reformation had been suppressed, starting with the era of Jan Hus spanning the defeat by Catholic Habsburgs at Bíla hora in 1620 and the subsequent emigration of prominent personalities of Czech spiritual culture headed by John Amos Comenius. According to Masaryk, a condition for moral education was the termination of Catholic clericalism in the Czech territores (moral - without catechism), the end of "suffering patriotism", and a transition towards the love of humanity - the message of Comenius's pansophism in terms of practical religiousness (Masaryk, 1990, pp. 39-46) - and towards democratization. When determining the goals of the new Czechoslovak educational system, Masaryk used the word de-Austrianization. ${ }^{1}$ By education for patriotism he wanted to encourage national sentiment as something to which morality would be bound instead of being bound to discredited religious sentiment (Masaryk, 1990, p. 105). The encouragement of tolerance instead of hostility was to be the main benefit of laymanization.

One of the most important tools of moral education according to Masaryk was a teacher's spontaneity and authenticity. The teacher should demonstrate humanity, he should not be afraid to show that he can be make mistakes, and he should not build a wall between himself and the students, as is the case with teachers who present opinions they do not identify with

\footnotetext{
${ }^{1}$ Today, however, the perception of this word in the Czech Republic is sometimes contrary, as Petr Jemelka notes: "The relationship to the Austro-Hungarian monarchy ... takes on a remarkably affectionate, nostalgic form today, where the designation »the jail of nations « has been forgotten" (Jemelka, 2014, p. 34).
} 
(such as legislation or directives issued by the principal, the mayor, a clergyman, etc.). According to Masaryk, inauthenticity is a false endeavour that students will sense immediately, which will result in the teacher's loss of authority and the loss of a prospective model of virtue. That is a great pity for moral education, according to Masaryk, and one of the reasons why he promoted the school's and teachers' independence not only from the church, but also from the state and everyone else who could interfere in it in a direct way (Masaryk, 1990, p. 64).

Apart from Masaryk, moral education has been discussed by several other authors. František Krejčí represented positivistic research ethics, by which he moved towards an apolitical attitude and religious independence (Krejčí, 1920, p. 20). By contrast, František Mareš (1925) reasoned against the positivistic derivation of morality from nature, because the cycle of nature often stands in opposition to man's moral ideas; therefore, he advocated morality on the basis of metaphysical absolute truth. In 1927, Karel Štěch discussed the topic in his extensive work Česká mravní výchova (Czech Moral Education) (Štěch, 1927, pp. 34-38). By drawing attention to the great personalities of Czech history, to which he added the still living Masaryk, he brought the focus of moral education back to the question of the Czech, national cause. "In order to be successful, moral education requires a favourable moral environment, which the period of servitude of the Czech nation was not" (Štěch, 1927, p. 234). However, Stěch made the Czech question absolute to the point of nationalism, refusing everything that "did not have a higher interest in the indivisible whole of the nation and state" (Štěch, 1927, p. 52).

František Drtina's work (1930) also contains a reflection of the era combined with a modernist concept of moral education. Drtina maintains that the goal of moral education is to guide the student toward his self-preservation: For the sake of man himself and for the sake of progress, i.e. tasks given to humanity, these tasks being man's conquest of nature. Drtina, too, turned to Comenius and Masaryk for the ways of acquiring morality, which was through practical religiousness (Drtina, 1930, pp. 146-147).

The concentration of production in cities, which made people move to cities, increased the number of people without religion, which was likely the reason for the publication (1936), of a book by Vladimír Josef Novák, Josef Meisner and Otakar Pertold called Základy mravní výchovy pro bezkonfesní mládež (Elements of Moral Education for Non-Religious Youth). ${ }^{3}$ Apart from an account of the evolution of man, the book contains a chapter called Immortality of the living substance and eugenics, in which the authors suggest not only that institutionalised health registers should be introduced and kept, but they also advise young people to keep such records themselves, so as to prevent both family tragedies and a burden on society (Meisner, 1936, p. 93). Meisner proposed the principle: "Control your behaviour at least in such a way that it does not harm human society. ... Try to be useful to human society within your own limits! You have a duty not only to yourself and your family, but to the whole of your nation and humanity to care about your health and arrange your sex life in such

\footnotetext{
${ }^{2}$ The fact that thinkers referred to Masaryk as a moral authority and model led to multiple publications of the socalled Masaryk reader, which contained his most important texts. The first edition came out during the monarchy in 1911 and was published nine times. See for instance Masarykova čítanka (Uherské Hradiště 1911).

${ }^{3}$ The year 1936 was also the year of the publication of a central School Order, which not only prescribed forms of punishment of students, but also introduced punishment for teachers who punished their students inadequately (for instance, the teachers could lose their jobs permanently). Physical punishment and humiliating punishment had already been regulated by law during the reign of Empress Maria Theresa. The General School Order enforced in 1774 did not directly outlaw physical punishment at lower-level schools, but it recommended a different - mental - form of punishment. The Imperial School Order enforced a century later, in 1869, outlawed physical punishment altogether. But since physical punishment was banned again as early as during the First Czechoslovak Republic, by the 1936 law, which also introduced sanctions, we cannot be too idealistic about the ways discipline was exacted at schools (Rigel, 2012, pp. 12-16).
} 
a way that your children, your family, the state and human society do not suffer for your acts. If your generation is burdened, it cannot bring the world anything creative or beautiful - quite the opposite, and it becomes a huge national economic burden to the state budget" (Novák, Meisner \& Pertold, 1936, p. 94).

During the Protectorate, when intellectual activity was restrained due to the closing down of universities, a muted discussion continued to some degree in a similar spirit in illegal philosophical magazines. ${ }^{4}$ After the restoration of Czechoslovakia, the period of constructing socialism and communism arrived relatively quickly (after 1948), which had a huge impact on moral education. Ideology penetrated moral education largely through the Moral code of the constructor of communism, which was a kind of Ten Commandments of the totalitarian regime. After the revolution of 1989, just as during Czechoslovakia (1918-1938), it was again the then president (Václav Havel) who took the initiative to encourage morality. His speeches, moreover, drew directly on Masarykian humanist idealism personalised in the motto "Truth and love must prevail over lies and hatred." Jiř́ Sedlák noted that after 1989 there were efforts to transform ${ }^{5}$ the educational system under the slogan "to dematerialize" the materialistic education of the previous regime (Sedlák, 1993, p. 329).

The concept of Education for Citizenships drafted by a team mobilized around Peter Pit'ha after 1989 had a particularly strong relationship to ethical (moral) education. In the multidisciplinary conception of the subject, containing legal, economic, political, anthropological and ecological components and components related to the study of homeland, it was the ethical element that served as the connecting and uniting force. According to Pitha, Education for Citizenships could therefore also be called ethical anthropology. The dimensions forming the awareness of the complex image of social reality surrounding the student (for instance the sociological, legal and economic dimensions) should have moral foundations (Pit'ha, 1992, p. 17). Pit'ha emphasizes that "the ethical foundation is superior to everything else because a citizen is primarily and deeply neither a producer nor a consumer, nor is he a legal subject; he is simply a human being" (Pit'ha, 1992, p. 18). In this context, Pit'ha discusses the terminological difference between Education for Citizenships understood as a knowledge subject as opposed to a values subject. The former typically instructs the person on what they may or may not do, and the result of such an approach is someone who thinks little, is less responsible, and often has low self-esteem. By contrast, Education for Citizenships as a character development subject should produce morally mature individuals (honest, hardworking, reliable, thoughtful), who will enhance the overall sophistication of the country, which is determined by the cultivation and quality of interpersonal relationships (Pit'ha, 1999, pp. 141-142).

This conceptual focus asked for an adequate methodological grip on the subject. Pitha talked about the necessity of introducing activation discussion and performative methods into teaching. For these methods to be effective, he also stressed that appropriate number of classes should be allocated for the subject, and he proposed the form of block scheduling (Pit'ha, 1992, p. 24). To develop an individual's moral qualities, ethics itself must nurture instead of just teach about morality (Pit'ha, 1999, p. 143).

Educational goals have changed since $2005 .{ }^{6}$ In addition to the cognitive dimension, school reforms started to focus on the performative dimension through developing competences. In this way, education for morality also acquired a new dimension, although it remained part of

\footnotetext{
${ }^{4}$ In Filosofická revue (1941), Metoděj Habáň defends the Aristotelian-Thomistic ethics as natural ethics (Zouhar, 2006, pp. 56-60). Among other philosophical journals were Ruch filosofický (Philosophical Hustle) and Česká mysl (The Czech Mind).

${ }^{5}$ In the transformational period after the 1989 revolution, as during the First Czechoslovak Republic (19181939), moral education was integrated into other subjects, particularly Education for Citizenships.

${ }^{6}$ On the basis of the school act of 2004 (Act no. 561/2004).
} 
the so-called hidden curriculum. The following text deals with moral education in the form of an independent subject called Ethical education; with moral education integrated into other subjects (curriculum analysis); and finally with moral education in school climate.

\section{Ethics as an independent subject (education for prosocial behaviour)}

Since 2010, after several discussions involving experts, a complementing educational discipline - Ethics ${ }^{7}$ was added to the Framework Programme for Education (RVP, Rámcový vzdelávací program - curriculum). ${ }^{8}$ Schools could decide to include ethics in their instruction as an independent subject or as a cross-curricular subject area integrated into several subjects. The main difference from the previous period was its comprehensive form defined in a separate curriculum document.

This newly created, complementing educational discipline draws on an existing project by Roche Olivar of The Autonomous University of Barcelona and its Slovak adaptation (by Ladislav Lencz), which were presented in the Czech Republic by the non-governmental organization Etické Fórum. ${ }^{9}$

Olivar's project, which represents education for prosocial behaviour, belongs to the socalled normative concept of moral education, which was developed in the North American environment by the psychologists Edward A. Wynn, Kevin Ryan and Thomas Lickona within the Character Development Project. Another project carried out in the same framework was the Child Development Project by Dan Solomon and others, whose purpose was to encourage prosocial behaviour, moral awareness and social adaptation. It was this project that Olivar built on (Olivar, 1992). According to Olivar, prosocial behaviour is an essential factor for the positive moral development of individuals. ${ }^{10}$

Olivar's ethical education is divided into four components:

- Educational programme promoting positive personality development; its starts with education for prosocial behaviour, which is then implemented into various spheres of life.

- Educational style, which creates a positive atmosphere through the positive acceptance of the individual (the student).

- Educational methods, which consist of several steps - cognitive sensitization, value reflection, exercising social skills in the classroom, real-time experience (Olivar describes the methods generally as experiential, i.e. methods where the pupils learn from their own experience)

\footnotetext{
${ }^{7}$ Ethics understood as prosocial education is a supplement to the Framework Programme for Education (RVP, Rámcový vzdelávací program) in both primary and secondary education. (RVP ZV is an abbreviattion for the Framework Programme for Education for Primary Schools; RVP G is an abbreviation for the Framework Programme for Education for Grammar Schools).

${ }^{8}$ At a 2009 conference on the importance of ethics in Czech schools, leading experts discussed whether ethical education should be education for prosocial behaviour. Prof. Pit'ha was positive: "Ethics should actually be called prosocial education, because it helps create qualities and abilities necessary for life in society... The reasons for implementing it are simple: It is a necessity. A school without character development is not a school, and society without morality has no future. It will suffer from an internal crisis and become easy prey for a dull dictatorship." (Pitha, 2009, p. 3).

${ }^{9}$ Its website: http://www.etickeforumcr.cz.

${ }^{10}$ Prosocial behaviour can be designated as helping behaviour (Výrost \& Slaměník, 2008, p. 285), i.e. behaviour that helps others and gives them certain benefits. The term itself first appeared in 1967. It represents a wide range of various helping activities, such as sympathy, gifts, support, help, invitation for cooperation. The related terms are solidarity, support, cooperation (Mlčák \& Záškodná, 2009, pp. 13-14). The term altruism, which is often confused with prosocial behaviour, is a category in its own right. Altruistic behaviour is such helping behaviour which is not connected with expectations of reward. This follows also from the generally accepted definition of altruism as voluntary behaviour aiming to provide help which requires sacrifice and whose motif is not the expectation of material or social reward (Nakonečný, 2007, p. 109).
} 
- Developing prosocial behaviour; the three previous components are chosen so as to develop prosocial behaviour (Olivar, 1992, p. 5).

The highest level of prosocial behaviour is collective and complex prosocial behaviour, focused on broader teams and social goals. It generalizes interpersonal relationships as social relationships, and its typical model is the family or school community. Complex prosocial behaviour is characterised by the active presence of various individuals and groups, who are either receivers or providers of prosocial acts. The so-called "intervention of a third party" can also occur, meaning that prosocial behaviour affects not only the direct receivers of prosocial acts, but also third persons and other social objects. The receivers of prosocial acts can be people or so-called "external social objects" such as religious or social norms and ideals. The "paradox of a prosocial act" means that certain prosocial acts are helpful for one group, while they negatively affect another group. Also Olivar notes that this complexity poses many questions, particularly in child rearing (Olivar, 1992, p. 121).

Prosocial behaviour is based on corresponding social skills, such as empathy, assertiveness and cooperation. By engaging pupils in social and cooperative activities, schools can help form their prosocial qualities. The cultivation of empathic skills develops prosocial behaviour fundamentally. According to Olivar, empathy even forms the basis of prosocial behaviour (Kasíková et al, 2011, p. 301). Abilities for empathy develop through empathic behaviour modelled by the teacher, which in turn favourably affects the pupils' empathic development (Nakonečný, 2000, pp. 275-276).

The Czech adaptation of prosocial education did not escape the basic shortcomings of the concept despite the fact that Roche's project is of an older date and the adopted Slovak adaptation took place in the 1990s. Its main shortcomings are a lack of pluralism in the basic orientation (one-sided prosocial orientation; although pupils can hold different opinions and discussion is encouraged, they are literally "trained" to become prosocial, which borders on manipulation), the inclination towards Catholic education (Štěrba, 2011, p. 140), and the prevailing psychological dimension ${ }^{11}$ and missing philosophical dimension (Gluchman, 2009, pp. 59-60).

Also the effectiveness of prosocial education itself is uncertain. Two long-time teachers of ethics, examining the effectiveness of prosocial education in their own research, with hypotheses about improved relationships in their classrooms, ended up with contradictory results. The effectiveness was, paradoxically, not proven in dissertation research by Pavol Motyčka of Etické fórum, the organization that promotes the need for Ethics and trains teachers for the subject. ${ }^{12}$

\section{Moral education outside the subject Ethical education}

Ethics is a facultative (supplementing) subject at primary and secondary schools and is not taught at all schools. In schools where Ethics does not exist as a subject, moral education is implemented through curriculum goals (RVP), which schools adapt to their own needs, maintaining the compulsory components. The goals also include moral goals, in the form of affective goals. What moral education are pupils and students given at these schools?

The aim of primary education is "to provide solid, basic education focused above all on life-like situations, but also on practical doing" (RVP ZV, 2013, p. 8). Pupils are prepared for these situations and doing by acquiring key competences (learning competences, problem-

\footnotetext{
11 Ethics should not be merely manipulation and psychosocial training, as is the case with the current programme. It is also strange that the subject's content has little to do with ethics as a discipline, and the subject can be taught by psychologists rather than ethicists.

${ }^{12}$ Motyčka's research did not confirm the hypotheses about the presumed positive increase in trust, improved relationships and fewer behavioural problems in the classroom (Motyčka, 2013, p. 137). By contrast, David Vaněk's dissertation research did confirm the hypotheses (Vaněk, 2011, p. 167).
} 
solving competences, communicative, social, personal, civil and work-related competences) across all subjects in the course of primary education. The purpose of competence goals as defined in the curriculum is to prepare pupils for independent survival in an individualized, changing and heterogeneous society with emphasis on responsibility and tolerance (RVP ZV, 2013).

Furthermore, pupils are educated through character development cross-curricular subject areas, which schools must integrate into compulsory subjects or create a new subject. The cross-curricular areas are: Social and personality education, Multicultural education, Environmental education, Media education, and Education for thinking in a European and Global context. As educational areas, these cross-curricular themes have their goals divided into areas of skills and knowledge, and attitudes and values. Their purpose is to guide pupils towards tolerance of diversity, and critically, assertively and keenly against stereotypes and hostility; guide them towards responsibility for their own lives and the lives of others, for nature and the environment; towards a positive view of oneself, self-discipline, and selfidentity; towards positive attitudes to their own values (national, European, civilizational) and foreign values; towards pluralism and compromise; and towards the will to help the weak (RVP ZV, 2013, pp. 104-117).

These affective goals confirm the trends in the key competences mentioned above. They can be summed up in the motto: Live and let live, or Live happily and let others live happily, too. In other words, an individual happy life is only possible in a tolerant, pluralistic and democratic environment. These principles are reminiscent of eudaimonistic Aristotelian ethics and politics, ${ }^{13}$ where individual happiness, searching for which is fully legitimate, can be sought and found in a well-organized society. ${ }^{14}$

In everyday practice, moral education (addressed in the goals of key competences, the goals of cross-curricular areas as well as the goals of the facultative complementing subject Ethical education) is realized through school subjects, both science and humanities, of which the most important are the character development subjects (Education for Citizenship, education for health, physical education, Czech language and literature, but also history, etc.), as these subjects provide the largest space for incorporating and implementing value and attitude goals. However, important educational tools for encouraging morality are also applied in science subjects. One of them is the tool of askesis, the practice of will and self-discipline, which learning in general requires. ${ }^{15}$

To sum up this section of our study, Czech primary schools educate using activation methods, by which pupils acquire the right habits: They practise will and self-control; become stronger in their tolerance of diversity and other (democratic) opinions; are given the opportunity to search for their identity and be authentic; and are encouraged to demonstrate their independence (opinions, projects, autonomous decisions).

Finally, an important factor in the moral education of pupils at primary schools is the morality of the teachers and the school management, which is reflected in the school's climate. In the introduction to the RVP, the Ministry of Education provides only a brief and general definition of school climate: "Create a favourable social, emotional and working climate based on effective motivation, cooperation and activation teaching methods; maintain the natural heterogeneous groups of pupils in education as long as possible, and eliminate the

\footnotetext{
${ }^{13}$ Of course without democracy.

${ }^{14}$ For instance, the introduction to the description of the cross-curricular area Personality and social education of the RVP for primary schools reads: "A specific trait of Personality and social education is that the pupil himself, the particular pupil group and the more or less ordinary situations of everyday life become a learning resource. The purpose of the cross-curricular area is to help each pupil find their own way to satisfaction in life based on good relationships towards themselves, other people and the world" (RVP ZV, 2013, p. 105).

${ }^{15}$ For instance, one of the goals in the educational area Mathematics and its integration is "to develop continuous self-control, systematic approach, perseverance and precision" (RVP ZV, 2013, p. 27).
} 
reasons for sorting pupils into specialized classrooms and schools" (RVP ZV, 2013, p. 6). We would like to point out that this brief requirement about school climate only reflects the goals we defined above, and sadly does not impose any new demands on schools. School climate is thus always a matter of each individual school, and it is a pity that detailed guidelines similar to those on educational goals do not exist in this area.

\section{Moral education at secondary schools}

Moral education has the same or similar position in secondary education curriculum documents as in primary education. However, ethics at secondary schools has been part of the curriculum for a longer time (since 2006), it has the same programme as ethics at primary schools, and isof prosocial focus. Thanks to the same structure, the curriculum builds on and reinforces the same key competences (which include competences for enterprise instead of work-related competence). ${ }^{16}$ What is interesting, however, is that despite the high number of affective and performative goals, the expected outputs (what the pupil should know at the end and what he should do during the lesson) are mostly cognitive. ${ }^{17}$

There is an obvious difference in the demands made on students of grammar schools and those of secondary vocational schools. In the latter schools there is, naturally, less space for theory and character development goals because the students are trained in their trade directly in the working environment of a particular company. However, that poses an interesting question about the reduction in value and moral goals, which these students miss out on. ${ }^{18}$

\section{Problems and practice}

According to Pavel Vacek, integrating moral education into all subjects is an illusion. All subjects contain and teach the values of tolerance, discipline, honesty, responsibility and care, but these are merely side-products in acquiring different knowledge and skills. In the end, the reality somewhat resembles: "everywhere, but in fact nowhere" (Vacek, 2011, p. 124). He argues that at school students do not encounter moral categories at all. ${ }^{19}$

This trend has been confirmed by a questionnaire study among the students of Education for citizenship at the Department of Education for Citizenship Education, Faculty of Education at Masaryk University in Brno carried out in April 2016. Out of 105 students, 88 students $(83.8 \%)$ said that they never had had ethics as a subject, while 17 students $(16.2 \%)$ said they did have the subject, or that ethics had at least been an elective at their schools.

It may seem that these answers confirm the assumption that moral education in the Czech Republic is not applied ${ }^{20}$ through the subject Ethics, but rather through the attitude and performative goals and output of the Framework Programme for Education. As mentioned above, this approach requires an activation form of instruction (practising the desired behaviour) and discussion ${ }^{21}$ (forming opinions and attitudes). Since competence goals and compulsory character development cross-curricular themes at primary schools are, naturally, best achieved in the subject Education for Citizenship, we further inquired of our students about what form their Education for Citizenship had taken. Again, the results did not meet our

\footnotetext{
${ }^{16}$ It is also divided into the same educational areas and cross-curricular themes.

${ }^{17}$ Compared with the cognitive outputs, purely affective outputs are very few in the educational area Man and society (Education for Citizenships and humanities basics) (RVP pro gymnázia, 2013 pp. 38-46).

${ }^{18}$ The programmes of RVP for vocational education are available at http://www.nuv.cz/t/rvp-os.

${ }^{19}$ The situation was not favourable even before the 2005 implementation of the RVP, which gave schools a partial autonomy: Vacek presents the results of his older research, where he studied teachers' and pupils' opinions on how well Czech education manages to influence moral development of pupils. The results were not a good testimonial: only $9 \%$ of the teachers and $9.5 \%$ of the pupils were positive, while $37.7 \%$ of the teachers and $42 \%$ of the pupils were very critical about the situation (Vacek, 2011, p. 158).

${ }^{20}$ Or applied to a limited extent (in both primary and secondary schools).

${ }^{21}$ And of course other tools, which cannot all be listed here.
} 
expectations: $12.3 \%$ said that instruction had almost always taken the form of lectures and the students' role had been passive; $47.6 \%$ said that instruction usually had taken the form of lectures and the students could ask questions; $22.8 \%$ said that instruction had taken the form of discussion (not only about the subject itself); $15.2 \%$ said that they had mostly discussed and worked on projects; and $1.9 \%$ said that discussion and projects had dominated instruction.

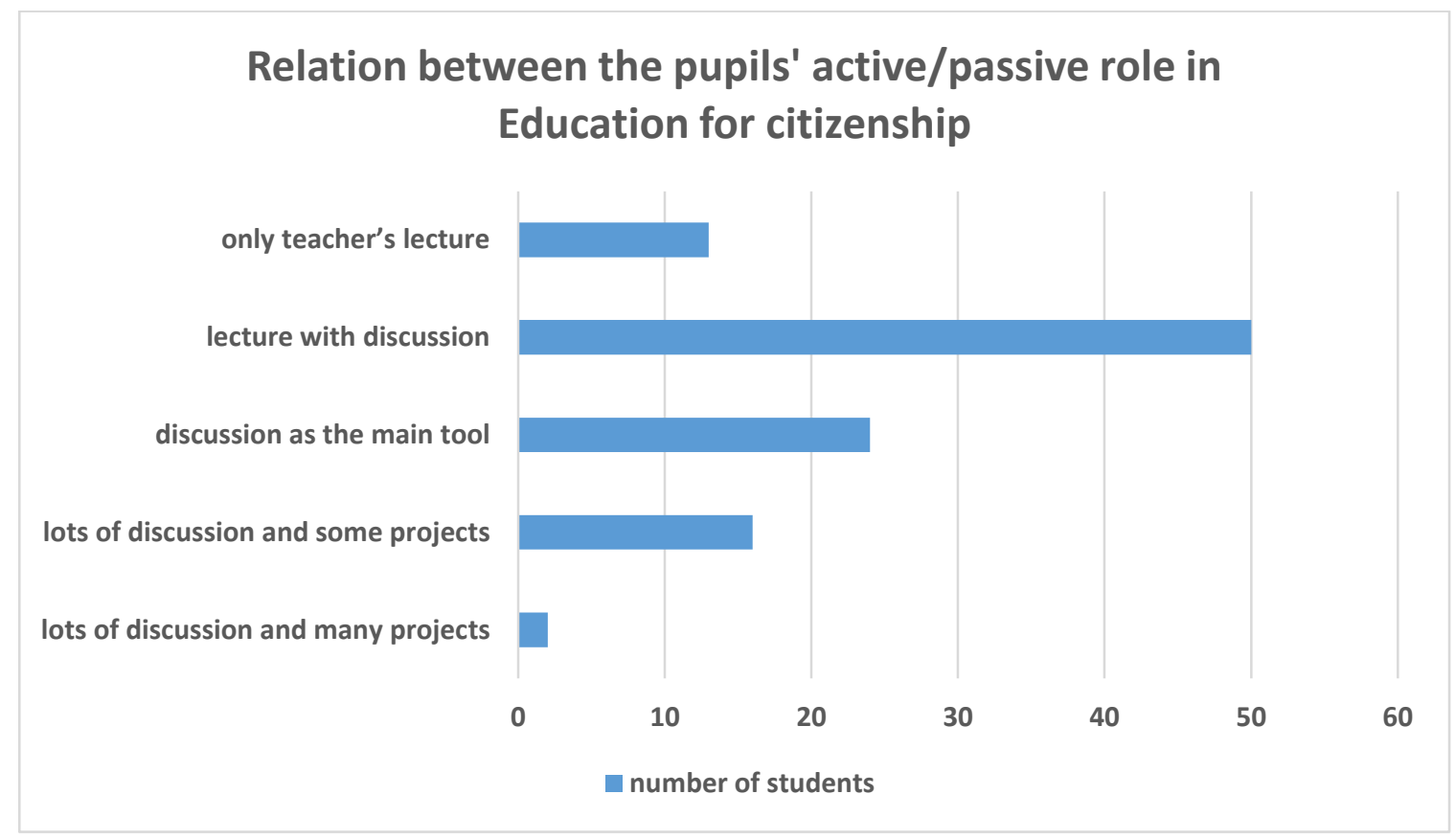

As we can see, in the first two groups the students were educated for citizenship through teachers' lectures, and their active participation was poor - they were passive or mostly passive (totally 59.9\%). In the third group, instruction was mostly carried out through lectures, but the pupils had better access to discussion. This means that for more than half of the pupils, moral education by achieving performative and affective goals did not take place, or took place only in a limited way. We assume that schools often do not pursue these goals, and still focus rather on cognitive output - lecturing rather than developing character, and educating through skills and attitudes.

Therefore, we tried to find out whether the students perceived the morals and morality of their former teachers and school management in their acts, and whether they perceived a consistent ethical climate in their school. We asked them the question about teachers' collegiality and loyalty. As for primary schools, 83 students $(79 \%)$ recalled their teachers' loyalty, while 18 students $(17.1 \%)$ recalled the opposite, and four students could not remember. For secondary schools the results were worse: 68 students $(64.7 \%)$ recalled loyalty/collegiality, while 34 students $(32.3 \%)$ recalled the lack of it, and three students $(2.8 \%)$ could not remember. ${ }^{22}$

The conclusion drawn from the study is that although moral education consists of three components, the first component - the elective ethics - does not find its way into the instruction, or the teacher is unable to implement it despite his training. The second component -compulsory ethics through RVP goals and outputs - is more or less a declared goal, and is accomplished to a lesser degree. The third component - the way that moral

\footnotetext{
${ }^{22}$ The different results at secondary schools are probably due to a more critical view of teachers by older students, but also to the students' fresher memories of recent times. It is also possible, however, that teachers pay more attention to their own shortcomings in the presence of younger children.
} 
education is executed through the school climate, morals and morality of teachers - is present at school under all circumstances, whether the first two components are present or absent, and the third component can negate the other two. The third component represents the oldest approach to moral education, and the obvious independence of this component suggests that it is also a natural approach. We can call it teaching by example, which is known as virtue ethics.

It appears that more important than relying on the educational program through RVP is to care about the ethical climate, which pupils notice. ${ }^{23}$ In this perspective, introducing evaluation schemes of values, school climate and pupils' character formation (from the Character Development Project by Thomas Lickona and Matthew Davidson), as suggested by Vacek, makes sense, and a given school informs parents about the level of ethical climate at school (Vacek, 2011, pp. 149-150). That means that schools form the climate and pupils' characters consciously, and these are first discussed and reflected on inside the school and then transferred into the spheres of parents and mutual relationships. In this way, the pupil sees a teacher who, thanks to discussions about the conscious formation of the educational environment, is capable of taking a clear moral stance that corresponds not only with the other teachers, but also perhaps with the parents. More important than such concordance, however, is the process of discussion itself and engagement, as Hegel reminds us in a story: "When a father inquired about the best method of educating his son in ethical conduct, a Pythagorean replied: Make him a citizen of a state with good laws" (Hegel, 1991, p. 196).

Of course, the importance of ethical climate, role models and engagement does not mean that moral education realized through the subject Ethics ${ }^{24}$ or through RVP goals ${ }^{25}$ is meaningless. Rather, it shows that teachers need to be prepared for creating such a climate, and that there exists an increased need for implementing professional teaching ethics into the education of both current and future teachers. In this way, teachers could better accomplish the attitude outputs of the curriculum and would acquaint themselves with tools useful in creating an ethical climate and in moral decision making in their profession.

\section{Moral education in the university environment}

University students can encounter the most widely known tool of professional ethics - the Code of ethics - on websites of most (if not all) Czech universities, ${ }^{26}$ and will probably transplant this tool to their future workplaces (provided that they acquaint themselves profoundly with the function and meaning of the code). If the parents' increasing informedness about school life, and the trend towards assuming the mentality of unsatisfied consumers (Lipovetsky, 2007, p. 394) in all spheres of life continues, we can expect a growing engagement of parents at schools. With the continuing trend towards the 'customer' mentality ${ }^{27}$ parents themselves will demand more and more information about the school's

\footnotetext{
${ }^{23}$ An example from real life is the cheating of a whole class on a final maths test (in a faculty school of the Faculty of Education, Masaryk University, in 2015/2016), which the students gained in exchange for another (biology) test with another class. While one of the teachers noticed that the results were suspiciously good and did not call attention to the situation, the other teacher, who taught a more "serious" subject, did call attention to the situation, by which he also revealed the first teacher's indifference to cheating. Had he not intervened, the students would have accepted dishonest behaviour, but now they had to talk about it (it was the topic of the month) and bear the consequences.

${ }^{24}$ We have reservations about its current form and content, though.

${ }^{25}$ Today, however, they are rather declaratory - as shown in the low number of synthesis and attitude outputs of the RVP. Moreover, even these are not applied, due to the passive role of the pupil in the classroom, as shown in the study on the subject Education for Citizenship education.

${ }^{26}$ For instance the Ethical code of Masaryk university, home university of the authors of the article: https://www.muni.cz/general/legal_standards/ethics_code?lang=en

27 According to Lipovetsky, the dissatisfied consumer mentality turned out to be beneficial in the increased happiness in partner relationships mostly for women (Lipovetsky, 2007, pp. 149-162).
} 
climate and the school's goals, vision and values, the progress of their children, etc. This will in turn increase the demands made on teachers and their professionalism and ethical awareness, and better tools will be required for facilitating discussions about compromises in seeking and defining the (pupil's, school's, society's, teachers') good at school. An increasing number of publications from applied and particularly professional ethics reflects this tendency, but courses in professional ethics at Czech universities do not reflect it yet. ${ }^{28}$

\section{Recognition instead of misrecognition, and a stop to technological objectivization (Recommendations for moral education through the RVP)}

It follows from the above stated that advocating education for tolerance and diversity (and positive recognition of minorities) through the goals and outputs of the curriculum is insufficient, and must be done through the school climate as well (this requirement, however, is articulated in the RVP for primary schools only insufficiently). The curriculum could reinforce this important educational component by recommending and demanding that school should be a place where minority children also feel good - that the school should also become their school. This prevention of double morality in the question of misrepresented minorities ${ }^{29}$ could be articulated in the RVP as a recommendation that libraries should enrich their resources with minority literature, that schools should teach minority literature and the history of minorities (the RVP does not require any cognitive outputs on Roma history except the holocaust in general terms), that they should use role models from among minority groups, that schools should also visually demonstrate that they are schools for everyone, etc. (Lesňák, 2013, pp. 87-95).

Our second remark on school climate is a suggestion to incorporate some kind of technological scepticism, since in technological civilization, the Czech school is becoming technological $^{30}$ in a number of ways. Firstly, it is crowded with technology of all kinds; secondly, it increasingly uses technology for education and relies on it; and thirdly, the pupils themselves are "armed" with technology both at school and outside of it. Despite the growing number of schools on the market offering a "natural" school (usually nursery schools in a forest), most schools market themselves as technologically well-equipped schools accessible through various applications and the Internet. So the Czech school does not help pupils free themselves from their dependence on technology - it does not help them transform themselves from the tool (object) of technology into a free Jonasian subject. An example of this is a note in the RVP regarding the cross-curricular theme Environmental education on how it can be suitably incorporated into the (compulsory) educational area Information and communication technologies (ICT): "In the educational area ICT, the cross-curricular theme provides opportunities for the use of computer technologies (Internet) for searching for up-todate information about the environment, discerning the gravity of ecological problems and realizing their interconnectedness. Communication technologies encourage interest in the ways ecological problems can be resolved through the possibility of making contacts and exchanging information within the region, the country, the EU and the world" (RVP ZV, 2013, p. 113). We agree that obtaining information about the world by means of technology is suitable, but we believe that the RVP does not encapsulate the problematic relationship between technology and environmental problems, or it even ignores it.

\footnotetext{
${ }^{28}$ Masaryk University (the second largest university in the Czech Republic) currently provides only one course in professional ethics (nursing ethics).

29 As Charles Taylor with colleagues note in their book Multiculturalism: (Expanded Paperback Edition) (Princeton: Princeton University Press, 1994).

${ }^{30}$ Regarding the terminology, see Jonas, H. (1985): The Imperative of Responsibility: In Search of an Ethics for the Technological Age. Chicago: University of Chicago Press.
} 
We would like to elaborate on this technological scepticism by adding contra-natural cultural scepticism in general. The basis of this standpoint is the ontological context of an oppositional standpoint of human culture (as a created, artificial environment) at the expense of nature (as an original system). In the era of disappearing natural environment, this knowledge of man as an animal whose survival strategy lies in creating an artificial environment (and tools he uses to hunt, cultivate, work, etc.), is essential for understanding what is going on in the world. Simple, minimal ontological literacy gives everyday practical doing a new dimension and helps one understand the essence of environmental problems. ${ }^{31}$ So what matters is not only the technological equipment and dependence of schools on technology, but also creating a school climate based on the prevailing biophile culture instead of contra-natural culture.

\section{Conclusion}

If we now turn back to the early $20^{\text {th }}$ century and compare the content of the discussion on moral education with the present, we will observe that although the moral question is no longer understood as a Czech cause, the main controversy remains essentially the same. At the beginning of the century, the dispute was between idealists and positivists (science allegedly guarantees independence and pluralism), while today the dominant dispute is about moral education as one-sidedly prosocial education on the one hand and education in the spirit of content pluralism on the other.

The weak position of ethics (as prosocial education) in contemporary schools and the weak practice in the outputs of moral education in other subjects at both primary and secondary schools, as shown in our study, suggests that a new programme of ethics as a subject in its own right, which would be commonly accepted (pluralistic), should be introduced. Philosophical-ethical education (including teaching ethics) of future teachers of this subject would provide a stronger personal component for a desired, more intensive discussion between teachers and parents about the values and creation of ethical climate at schools and about pupils' character formation.

Slavomír Lesňák is assistant professor at the Department of Civics, Faculty of Education, Masaryk University. His main research interest includes the ethics of evolutionary ontology, history of ethics, and questions of misrecognition.

Radim Štěrba is assistant professor at the Department of Civics, Faculty of Education, Masaryk University. He specializes in civics didactics.

\section{Corresponding author:}

Slavomír Lesňák, Department of Civics, Faculty of Education, Masaryk University, Poř́íčí 31, 60300 Brno, Czech Republic

email: lesnak@ped.muni.cz

\section{References}

DRTINA, F. (1930): Spisy Františka Drtiny, sv. III. Ideály výchovy. Soubor programových a historických stati z pedagogiky [The Writings of František Drtina, vol. III. Ideals of Education: A Collection of programmatic and historical articles]. Praha: Jan Laichter.

\footnotetext{
31 "The cause of the crisis is a system conflict between the artificial cultural order and the natural order of the Earth" (Šmajs, 2015, p. 8). For more see e.g. Šmajs, J. (2008): Evolutionary Ontology. Reclaiming the Value of Nature by Transforming Culture. Amsterdam \& New York: Rodopi.
} 
GLUCHMAN, V. (2009): "Etická výchova" a morálne myslenie (etika sociálnych dôsledkov ako východisko modelu mravnej výchovy) ["Ethical Education" and Moral Thinking (Ethics of Social Consequences as the Basis for a Moral Education Model]. In: Š. Ligas (ed.): Mravná výchova v školách na Slovensku a v zahraniči. [Moral Education at Schools in Slovakia and Abroad]. Banská Bystrica: Pedagogická fakulta, Univerzita Mateja Bela, pp. 61-70.

HEGEL, G. W. F. (1991): Elements of the Philosophy of Right, trans. by H. B. Nisbett. Cambridge: University Press. Available at:

http://www.inp.uw.edu.pl/mdsie/Political_Thought/Hegel\%20Phil\%20of\%20Right.pdf JEMELKA, P. (2014): Výročí [Anniversary]. In: R. Rybáŕ \& S. Novák (eds.): Čtvrtstoletí polistopadového vývoje [A Quarter-Century of Post-Revolutionary Development]. Brno: Masarykova univerzita, pp. 25-35.

KREJČÍ, F. (1920): Filosofické základy mravní výchovy [Philosophical Elements of Moral Education]. Zábřeh na Mor.

KASÍKOVÁ, H., et al. (2011): Pedagogika pro učitele [Pedagogy for Teachers]. Praha: Grada.

LESŇÁK, S. (2013): Ďalších 20 rokov zneuznania Rómov v Čechách a na Slovensku. [Another 20 Years of Misrecognition of the Roma in the Czech Republic and Slovakia] In: R. Rybár \& S. Novák (eds.): Dvacet let samostatné České republiky [Twenty Years of the Czech Republic's Independence]. Brno: Masarykova univerzita, pp. 83-95.

LIPOVETSKY, G. (2007): Paradoxní štěstí. Esej o hyperkonzumní společnosti [Paradoxical Happiness. An Essay on the Hyperconsumer Society]. Praha: Prostor.

MLČÁK, Z. \& ZÁS̆KODNÂ, H. (2009): Osobnostni aspekty prosociálního chováni a empatie [Personality Aspects of Prosocial Behaviour and Empathy]. Praha: Triton.

MOTYČKA, P. (2013): Implementace doplñujicího vzdělávacího oboru Etická výchova $v$ České republice [The Implementation of Ethic Education as a Supplementary Educational Subject in the Czech Republic]. Praha: UK.

NAKONEČNÝ, M. (2007): Sociální psychologie [Social Psychology]. Praha: Vysoká škola obchodní.

NAKONEČNÝ, M. (2000): Lidské emoce [Human Emotions]. Praha: Academia.

MEISNER, J. (1936): Nesmrtelnost živé hmoty a eugenika. [Immortality of the Living Substance and Eugenics]. In: V. J. Novák, J. Meisner \& O. Pertold: Základy mravní výchovy pro bezkonfesní mládež [Elements of Moral Education for Non-Religious Youth]. Praha: Volná myšlenka, pp. 79-97.

OLIVAR, R. (1992): Etická výchova [Ethical Education]. Bratislava: Orbis Pictus Istropolitana.

PIŤHA, P. (2009): Etická výchova na školách - ano či ne? [Ethical Education at Schools Yes or No?]. Ministerstvo školství, mládeže a telovýchovy. [online] [Retrieved April, 09, 2016] Available at: http://www.msmt.cz/vzdelavani/referaty-z-konference-etickavychova?highlightWords=etick\%C3\%A1+v\%C3\%BDchova

PIŤHA, P. (1992): Úvod do výchovy k občanství: knižka pro učitele a veřejnost [Introduction to Education for Citizenship Education: A Bookfor Teachers and the Public]. Praha: Orbis.

PIŤHA, P. (1999): Učitelé, společnost a výchova. [Teachers, Society and Education]. Praha: Karolinum.

RÁMCOVÝ VZDĚLÁVACÍ PROGRAM PRO ZÁKLADNÍ VZDĚLÁVÁNÍ (2013) [Framework Educational Programme for Primary Schools]. [online] [Retrieved April, 17, 2016]. Available at: http://www.msmt.cz/vzdelavani/zakladni-vzdelavani/upraveny-ramcovyvzdelavaci-program-pro-zakladni-vzdelavani

RÁMCOVÝ VZDÉLÁVACÍ PROGRAM PRO GYMNÁZIA (2013) [Framework Educational Programme for Grammar Schools]. [online] [Retrieved April, 17, 2016]. Available at: http://www.nuv.cz/file/159 
RIGEL, M. (2012): Vývoj kázenských postihů na školách v českých zemích aneb vyhání metla děti z pekla? [The Evolution of Disciplinary Punishment at Schools in the Czech Lands, or Does the Broom Expel Children from Hell?]. In: Komenský, 137(2), pp. 12-16.

SEDLÁK, J. (1993): K didaktice etiky [On Ethics Didactics]. In: Filosofický časopis, 40(2), pp. 326-340.

ŠMAJS, J. (2015): Ústava Země. Filozofický koncept [The Constitution of the Earth. A Philosophical Concept]. Banská Bystrica: PRO.

ŠTĚCH, K. (1927): Česká mravní výchova [Czech Moral Education]. Praha: Ústřední nakladatelství a knihkupectví učitelstva českoslovanského.

ŠTĚRBA, R. (2011): Etická výchova, její pojetí a osobnost učitele [Ethical Education, Its Concept and the Teacher's Personality]. In: R. Rybáŕ \& S. Novák. (eds.): Člověk-společnost a výchova khodnotám [Man - Society and Education for Values]. Brno: Masarykova univerzita, pp. 135-149.

VACEK, P. (2011): Psychologie morálky a výchova charakterů žáki̊ [Psychology of Morality and Character Formation of Pupils]. Hradec Králové: Gaudeamus.

VANĚK, D. (2011): Rozvoj prosociálního chováni u žáki̊ II. stupně základni školy v kontextu Etické výchovy [Development of Prosocial Behavior among Second Degree Basic School Pupils in the Context of Ethical Education]. Brno: FSS Masarykova univerzita.

VÝROST, J. \& SLAMĚNÍK, I. (2008): Sociální psychologie [Social Psychology], 2nd ed., Praha: Grada.

ZOUHAR, J., PAVLINCOVÁ, H. \& GABRIEL, J. (2006): Filosofie za protektorátu. Vybrané texty z českých filosofických časopisü [Philosophy during the Protectorate. Selected texts from Czech Philosophical Magazines]. Brno: Masarykova univerzita. 